Journal of Applied Pharmaceutical Science Vol. 5 (06), pp. 058-065, June, 2015

Available online at http://www.japsonline.com

DOI: 10.7324/JAPS.2015.50609

ISSN 2231-3354 (cc) BY-NC-SA

\title{
Neuroprotective effects of I ndi gofera tinctoria on noise stress affected Wistar albino rat brain
}

\author{
Sakthivel Srinivasan, Wankupar Wankhar, Sheeladevi Rathinasamy, Ravindran Rajan \\ Department of Physiology, Dr. ALM PG Institute of Basic Medical Sciences, University of Madras, Taramani campus, Chennai-600 113, India.
}

\author{
ARTICLE INFO \\ Article history: \\ Received on: 07/04/2015 \\ Revised on: 10/05/2015 \\ Accepted on: 24/05/2015 \\ Available online: 27/06/2015 \\ Key words: \\ Oxidative stress, DNA \\ fragmentation, Antioxidant, \\ Motor coordination, Anxiety, \\ Behavior
}

\begin{abstract}
The objective of the study is to evaluate the DNA damage, behavior and free radical scavenging enzymes level when exposed to noise. Noise stress was performed using broadband white noise generator after pre-treated oral administration of Indigofera tinctoria $(300 \mathrm{mg} / \mathrm{Kg}$.b.w.). Significance increase in nitric oxide and lipid peroxidation level in stressed rat shows possibility of neurodegeneration and this is justified by genomic DNA damage in brain discrete region. Increase in enzymatic and decrease in non-enzymatic level suggest that oxidative imbalance persist in animal when expose to noise in both brain and adrenal. Anxiety and altered motor coordination was also observed in our studies, this finding could be attributed to the detrimental effects of noise not only at the biochemical level but also the molecular and psychological behavior of the rat. However, oral administration of I.tinctoria significantly prevented noise induced oxidative damages. These results conclude that I.tinctoria may possess neuroprotective effects and the antioxidant property of the plant may have resulted in its therapeutic efficacy.
\end{abstract}

\section{INTRODUCTION}

Stress is an integral part of human life, living beings when continuously exposed to stressful stimuli has been known to affect several physiological and psychological processes. Noise is a stressful stimulus if exceeded $90 \mathrm{dBA}$ becomes a source of stressor (Ramsey, 1982). Stress can stimulate the Hypothalamo-Pituitary-Adrenal (HPA) and increase the release of Corticotrophin Releasing Hormone (CRH) from the hypothalamic paraventricular nucleus, causing the secretion of adrenocorticotropin (ACTH) from anterior pituitary, which in turn stimulates the secretion of glucocorticoids from the adrenal cortex axis (Kvetnansky et al., 2002). Elevation in the corticosterone level accelerates the generation of free radical (McIntosh and Sapolsky, 1996). Generation of free radicals is a fundamental feature of normal cellular functions. However, excessive generation and inadequate removal of free radical results in destructive and irreversible damage to the cells (Lopaczyski and Zeisel, 2001). Over production of free radicals

\footnotetext{
* Corresponding Author

Ravindran Rajan, Assistant Professor, Department of Physiology, Dr ALM PG IBMS, University of Madras, Taramani Campus, Chennai- 600113, India. Email: drravindranrajan [at] gmail.com
}

can cause oxidative damage to biomolecules (lipids, proteins, DNA), eventually leading to many chronic diseases such as cardiovascular diseases, chronic inflammation, stroke, septic shock, aging and other degenerative diseases in humans (YunZhong et al., 2002). Various stresses have been associated with enhanced free radical generation causing oxidative damage. Oxidative stress arises from the imbalance between pro-oxidants and antioxidants leading to oxidative damage. Neural tissue is especially sensitive to oxidative stress because of the fact that brain cells are the almost vulnerable to free radical damage caused by lipid peroxidation compare with other tissues, owing to their highest percentage of unsaturated fats (Antonio, 2001). Antioxidants are classified as exogenous (natural or synthetic) or endogenous compounds, responsible for scavenging free radicals or inhibiting the binding of metal ions needed for catalysis of ROS generation (Gilgun-Sherki et al., 2001). Indigofera tinctoria (I.tinctoria) (Fabaceae) has been a part of Indian and Chinese medicinal systems since ancient times. The plant has been used for treatment of nervous disorders, liver ailments, epilepsy, cancer, inflammation, bronchitis and as ointment for sores, old ulcers and haemorrhoids (Renukadevi et al., 2011). But the effectiveness of aqueous extract of I.tinctoria in prevention of noise-stress induced animal models has not yet been studied. 
Hence, this present study was undertaken to evaluate the efficacy of I.tinctoria extract against the physiological and psychological changes in the rats when exposed to noise.

\section{MATERIALS AND METHOD}

\section{Extraction of plant extract}

The plant I. tinctoria was collected (May to November 2013) from the KSG Enterprises (Tindivanam, Tamil Nadu, India) and authenticated by Dr. D. Aravind (Department of Medical Botany, and National Institute of Siddha, Chennai, India). Voucher specimens were deposited at the Herbarium of National institute of Siddha, Reg no: NIS/MB/83/2013. The collected plants were separated from unwanted materials and dried in shade. The leaves were ground to coarse powder with the help of a suitable grinder. The powder was then stored in an airtight container, kept in a cool, dark and dry place until the analysis.

\section{Experimental design}

Wistar strain male albino rats weighing 180-220 g were randomly selected. The animals were maintained under standard laboratory condition and fed ad libitum with food (M/S Hindustan Lever Limited, Bombay, India) and water. All the rats were housed under condition of controlled temperature $\left(26 \pm 2{ }^{\circ} \mathrm{C}\right)$ with $12 \mathrm{~h}$ light and $12 \mathrm{~h}$ dark exposure. The animals were divided into four groups with six animals in each group. Group I served as the control, Group II animals were subjected to noise-stress for $4 \mathrm{~h}$ daily for 15 days (Sub-acute exposure), group III were treated with Indigofera tinctoria (IT) for 48 days and experiments were carried out on 49th day and Group IV consisted of noise with IT-treated animals. These animals were pre-treated with IT for 33 days and then exposed to noise stress for 15 days. During the noise stress period, they were also given IT extract by the oral route and all the experiments were done on the 49th day. Ethical clearance was obtained before the commencement of experiments from the ethical committee (IAEC No: 22/02/2013) and the Committee for the purpose of control and supervision of experiments on animals (CPCSEA).

\section{Noise stress induction}

Broadband white noise at 100-dBA intensity was produced by a white noise generator, amplified by an amplifier connected to a loud speaker fixed $30 \mathrm{~cm}$ above the animal cage. A sound level meter was used to measure the intensity of the noise (Samson et al., 2005).

\section{Sample Collection}

Isolation of brain region was performed between 8 to 10 a.m. to avoid circadian rhythm induced changes. The animals were sacrificed under deep anesthesia using Pentothal sodium $(40 \mathrm{mg} / \mathrm{kg}$ b.w). The discrete regions of brain (cerebral cortex, cerebellum, striatum, brain stem, hippocampus and hypothalamus) were dissected according the method given by Glowinski and Iverson, (1996). The brain regions was excised, washed in ice cold saline and blotted to dryness. Quickly weighed and the brain sample were homogenized by using Teflon glass homogenizers. 10\% homogenate of this tissue was prepared in phosphate buffer $(0.1$ $\mathrm{M}, \mathrm{pH} \mathrm{7.0)}$ and centrifuged at $3000 \mathrm{~g}$ at $4^{\circ} \mathrm{c}$ for $15 \mathrm{~min}$ to remove cell debris and the clear supernatant was used for further biochemical assays.

\section{Biochemical determinations}

Protein was estimated as per the method described by Lowry et al. (1951). Lipid peroxidation was determined in the tissue samples as described by Ohkawa et al. (1979). Nitric oxide (NO) levels were measured as total nitrite + nitrate levels with the use of the Griess reagent by the method of Moshage, (1995). Protein thiol by Sedlack and Lindsay, (1968) was determined. Superoxide dismutase (SOD) according to Marklund and Marklund, (1974) and catalase (CAT) according to the method of Sinha, (1972). The activity of glutathione peroxidase (GPx) was estimated by the methods of Rotruck et al. (1973). Reduced glutathione (GSH) in the tissue samples was estimated by the method of Moron et al. (1979). The vitamin-C (ascorbic acid) content in the tissue was determined according to the method of Omaye et al. (1979).

\section{DNA fragmentation assay}

Separation of DNA molecules from the extracted samples was performed by (Borriello et al., 2002).

\section{Behavioral analysis}

Motor co-ordination was assessed using the conventional Rota rod test (Dunham et al., 1957) and narrow beam (Kolb and Whishaw, 1983). Elevated plus maze was used to evaluate the anxiety status in animals (Pellow and File, 1986).

\section{Statistical analysis}

The results are presented with mean \pm S.D. The data statistically evaluated using one-way analysis of variance (ANOVA), followed by Tukey's multiple comparison tests in SPSS-20.

\section{RESULT AND DISCUSSION}

Noise is defined as disturbing, unwanted sound and its damaging effects particularly the productions of free radicals are not limited to the auditory organ (Reha et al., 2009). Oxygen free radicals can attack protein, nucleic acids and lipid membranes thereby disrupting normal cellular functions and integrity (Manikandan et al., 2005). In this respect, it is worthy to note that a brain antioxidant level is a main target of free radicals toxicity due to its high oxygen consumption.

\section{Free radicals}

Free Radicals are unpaired electron molecules and these molecules are highly reactive. Free radicals attack three main cellular components (Lipids, proteins and DNA). Nitric oxide is a 
highly reactive signal molecule in the CNS. It is a unique messenger molecule that serves diverse physiological functions throughout the body. The NO levels in various groups are presented as bar diagram with mean \pm S.D (Fig 1). Control groups when compared with I.tinctoria unaccompanied groups there is no changes observed. In sub-acute noise stress the NO levels are significantly $(\mathrm{P}<0.001)$ increase in discrete region of brain and adrenal. Elevated levels of NO have been found in increased nitrosative stress, leading to cell degeneration and necrosis. Predominantly the hypothalamus and adrenal showed continue increased nitric oxide level indicating that these areas are affected the most during sub-acute noise exposure. This justify that noise stress generate nitric oxide level in the brain and adrenal. This is agreement with Lidija et al. (2007) who reported that, the increase of NO production in distinct brain regions functionally connected via afferents and efferent suggests that these regions are affected by the injury. However, the plant I. tinctoria treated noise exposed group shows significant decrease in nitric oxide level by downregulating the activity. This because of plants contain several phytochemicals which possess strong antioxidant activities (Senthilkumar and Venkatesalu, 2009). The LPO data from various groups are presented as bar diagram with mean \pm S.D (Fig $2)$. LPO is a free-radical-mediated process. In sub-acute noise stress the LPO level were significantly $(\mathrm{P}<0.001)$ increased in rat brain and adrenal region, which also supports the generation of free radicals. This increased ROS leads to excessive membrane damage in brain region and the generation of reactive free radicals overcomes the antioxidant defense (Ashok and Sheeladevi, 2012). The I. tinctoria with noise group LPO level were significantly decreased in cortex $(\mathrm{P}<0.05)$, cerebellum $(\mathrm{P}<0.01)$, and hypothalamus $(\mathrm{P}<0.01)$ when compare with control and subacute noise exposure LPO level were decreased in cortex $(\mathrm{P}<$ 0.01). Protein thiol level are presented as bar diagram with mean \pm S.D (Fig 3). The activities of protein thiol are significantly ( $\mathrm{P}<$ 0.001) decreased in 15 days noise-stress group compare with control. This may have occurred due to oxidation of one of the major thiol substance. The present study also shows that, subacute noise stress lead to a significant elevation in free radical scavenging enzymes SOD, GST, CAT, GPx and decrease in GR levels hen compared with control, in brain and adrenal. SOD, CAT, and GPx are among the key enzymes that defend the contents of cells against presented as bar diagram with mean \pm S.D (Table1). In sub-acute noise stress SOD level in hippocampus, hypothalamus and adrenal continually increased, this representing that these areas are affected. Vidyasagar et al. 2004 who reported that, increased SOD levels were only partially effective in combating the oxidative damage. Since the increase in SOD activity may have caused by excess superoxide radical production, elevated lipid peroxidation in brain region is justified. In this respect, it is worthy to note that a brain antioxidant level is a main target of ROS toxicity due to its high oxygen consumption. This explains the reason for the increased production of free radicals in noise stress observed in this study. CAT and GPx from various groups are presented as bar diagram with mean \pm S.D (Table $2 \&$
3). The CAT and GPx levels are significantly $(\mathrm{P}<0.001)$ increase in 15 days noise exposure in all the regions of the brain and adrenal when compared with control. Increased SOD activity could naturally accumulate the super oxides and $\mathrm{H}_{2} \mathrm{O}_{2}$ which justify the increase in CAT and GPx for their increased activity after noise exposure. Catalase has been shown to be responsible for the detoxification of significant amounts of $\mathrm{H}_{2} \mathrm{O}_{2}$. Glutathione peroxidase metabolizes peroxides such as $\mathrm{H}_{2} \mathrm{O}_{2}$ and protects cell membranes from lipid peroxidation.

GST levels from various groups are presented in Table 4 with mean \pm SD. In sub-acute noise stress the GST levels were significantly $(\mathrm{P}<0.001)$ increased in both brain and adrenal. In noise stress exposure the adrenal to shows an increase GST activity indicating that these areas are affected. Glutathione reductase (Table 5) are significantly $(\mathrm{P}<0.001)$ decreased in both brain discrete regions and adrenal when exposed to noise stress. This is clearly justified that noise cause GST and GR levels in brain. The decrease in GST and GR activity could lead to imbalance in redox status due to decrements in the antioxidant activity ad this could be attributed to the decrease in major substrate such as GSH levels (Fig 4) in brain and adrenal. There is a chance between alterations in GSH with neurodegenerative disorders such as Alzheimer's disease, amyotrophic lateral sclerosis, schizophrenia, and Parkinson's disease are reported (Bharath et al., 2002). Loss of glutathione and consequent oxidative damage have been suggested to be early signaling events in apoptotic cell death. The decreased GSH levels is presumably due to enhanced utilization of reduced glutathione by glutathione peroxidase in detoxification of $\mathrm{H}_{2} \mathrm{O}_{2}$ generated by noise induced oxidative stress. Noise stress induced elevated free radical scavenging enzymes are significantly reduced in pre-treated $I$. tinctoria with noise stressed animals. The plant I. tinctoria has been reported that, contain potential of antioxidant and free radical scavenging activity (Nagarajan and Sellamuthu, 2013). This is explain that plant may enhance the free radical scavenge enzyme to scavenging the free radicals. The activity of Vit-C (Fig 5) were significantly $(\mathrm{P}<0.001)$ decreased in 15 days noise-stress group. Vitamins $\mathrm{C}$ and $\mathrm{E}$ have been found to be protective against noiseinduced cochlear damage (Seidman, 2000). In our study the subacute stress decreased the Vit $\mathrm{C}$ level. Vitamin $\mathrm{C}$ is a hydrophilic reducing agent which directly reacts with superoxides, hydroxyls and various lipid hydro peroxides more effectively than any other water soluble antioxidant. I.tinctoria treated with noise group displays significant increase in Vit-C levels compare with the stress group particularly in cerebellum, striatum, hippocampus and striatum, brainstem when compare with sub-acute noise group. This justify that plant contain natural antioxidant. This in agreement with Nagarajan et al. (2013) who reported that, the plant I.tinctoria contain potential of antioxidant and free radical scavenging activity. This results justify that, noise stress-induced alteration in the biochemical abnormalities was prevented in I.tinctoria supplemented group. Therefore the present study suggests that I.tinctoria supplementation may utilise antioxidant effect and can be regarded as a protective drug against stress. 


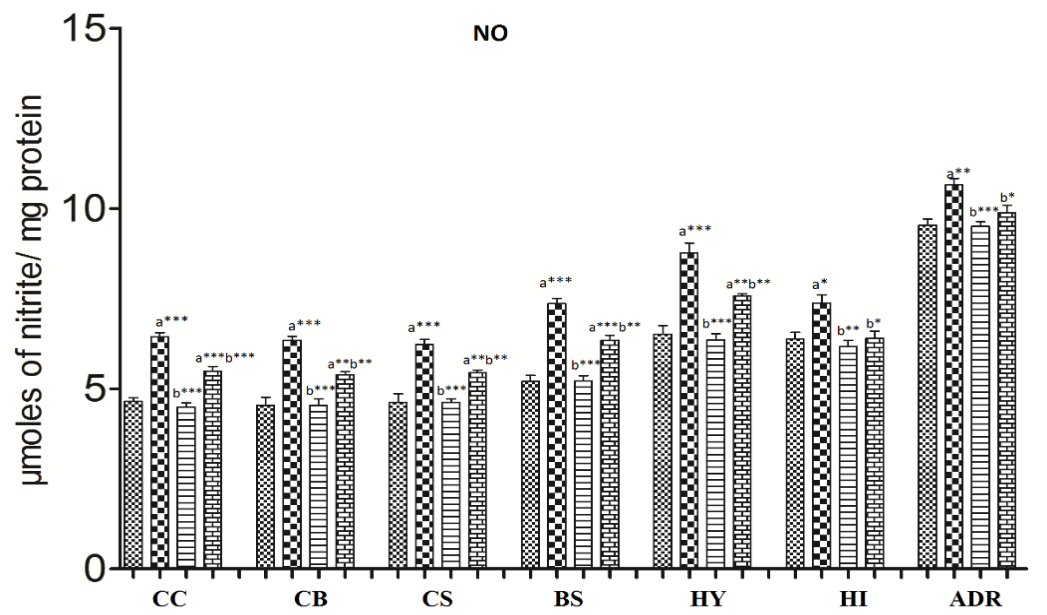

Fig. 1: Protective effect of I.tinctoria (300 mg/kg animal body weight) on Nitric oxide (NO) level in albino rats exposed to noise-stress ( $\mu \mathrm{moles}$ of nitrite/ mg protein). Values are expressed as mean \pm S.D of six animals. Significance at $* \mathrm{p}<0.05$; Significance at $* * \mathrm{p}<0.01$; and c- Significance at $* * * \mathrm{p}<0.001$. (CCCortex, CB-Cerebellum, CS-Striatum, BS- Brain stem, HY- Hypothalamus, HI- Hippocampus and ADR- Adrenal)

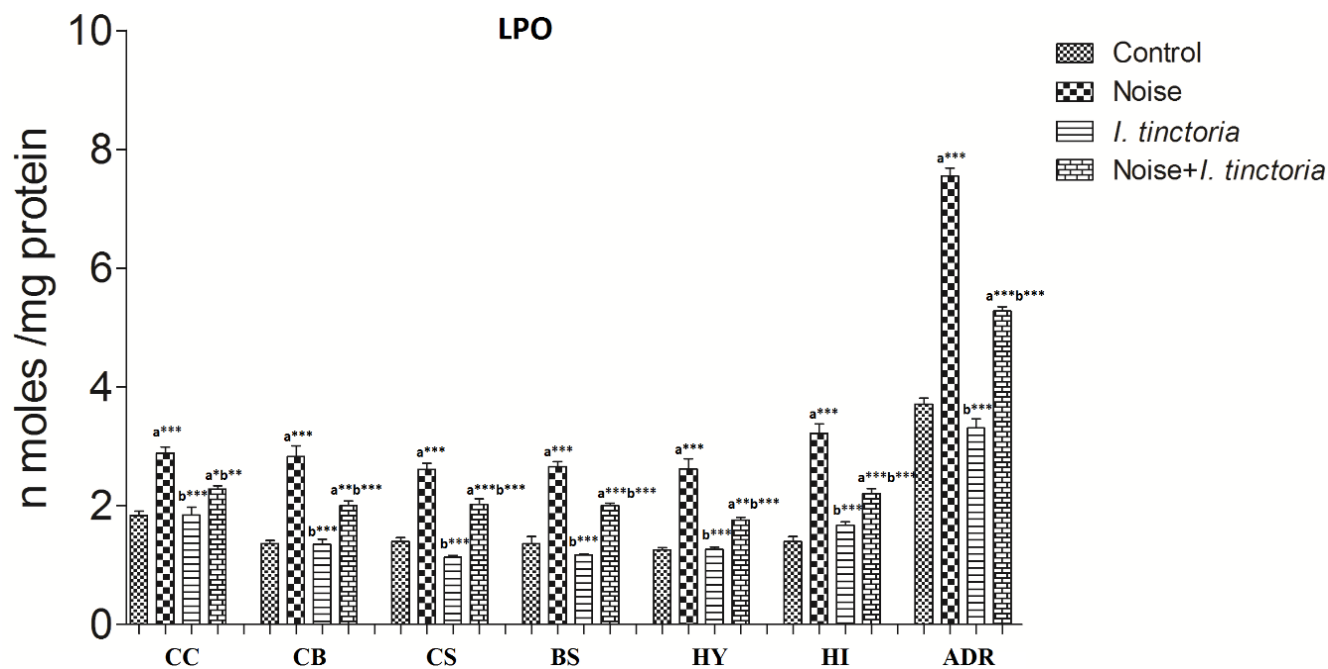

Fig. 2: Protective effect of I.tinctoria (300 mg/kg animal body weight) on Lipid Peroxidation (LPO) level in albino rats exposed to noise-stress (n moles /mg protein). Values are expressed as mean \pm S.D of six animals. Significance at $* p<0.05$; Significance at $* * p<0.01$; and c- Significance at $* * * p<0.001$. (CC-

Cortex, CB-Cerebellum, CS-Striatum, BS- Brain stem, HY- Hypothalamus, HI- Hippocampus and ADR- Adrenal)

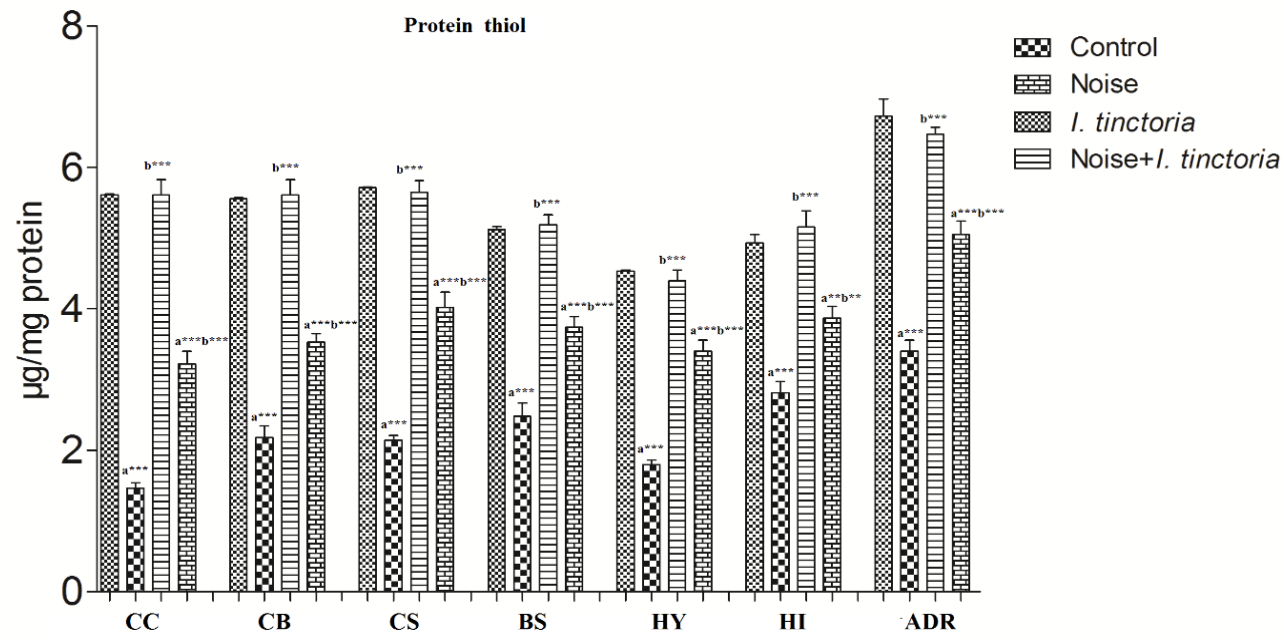

Fig. 3: Protective effect of I.tinctoria ( $300 \mathrm{mg} / \mathrm{kg}$ animal body weight) on Protein thiol level in albino rats exposed to noise-stress ( $\mu \mathrm{g} / \mathrm{mg}$ protein). Values are expressed as mean \pm S.D of six animals. Significance at $* p<0.05$; Significance at $* * p<0.01$; and c- Significance at $* * * p<0.001$. (CC-Cortex, CB-Cerebellum, CS-Striatum, BS- Brain stem, HY- Hypothalamus, HI- Hippocampus and ADR- Adrenal) 


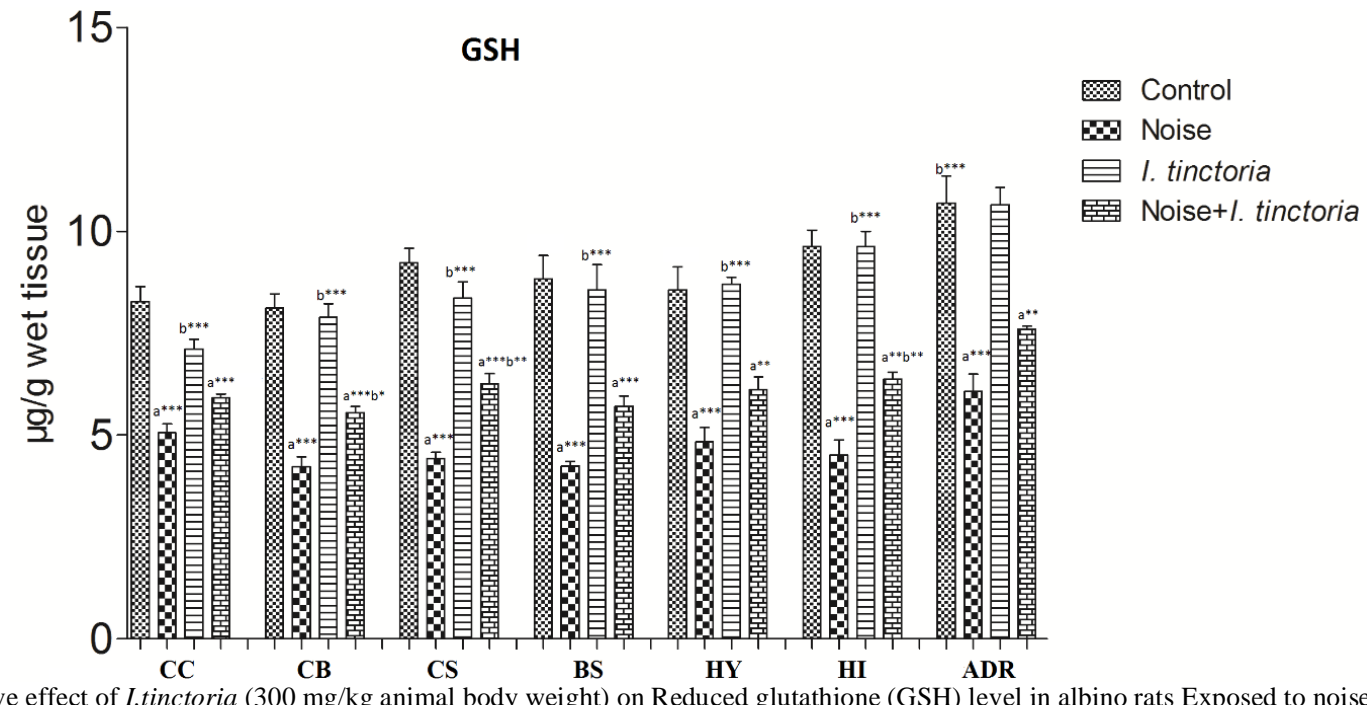

Fig. 4: Protective effect of I.tinctoria ( $300 \mathrm{mg} / \mathrm{kg}$ animal body weight) on Reduced glutathione (GSH) level in albino rats Exposed to noise-stress ( $\mu \mathrm{g} / \mathrm{g}$ wet tissue). Values are expressed as mean \pm S.D of six animals. Significance at $* \mathrm{p}<0.05$; Significance at $* * \mathrm{p}<0.01$; and c- Significance at $* * * p<0.001$. (CC-

Cortex, CB-Cerebellum, CS-Striatum, BS- Brain stem, HY- Hypothalamus, HI- Hippocampus and ADR- Adrenal)

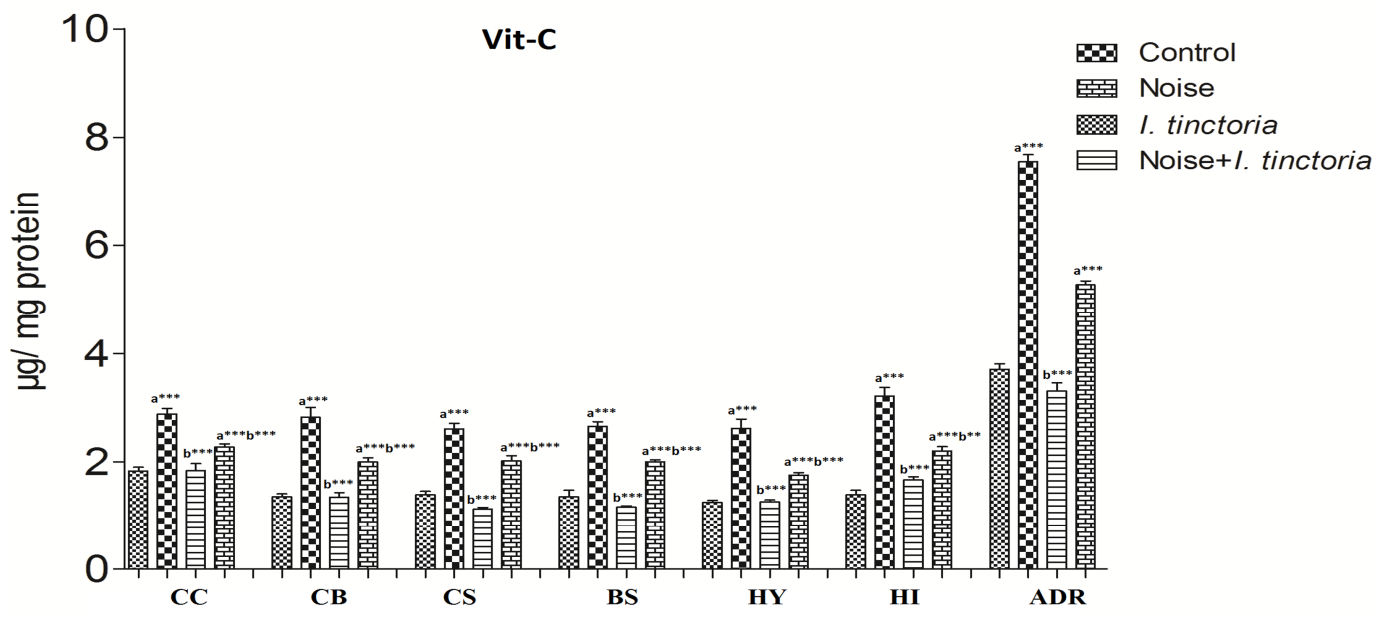

Fig. 5: Protective effect of I.tinctoria ( $300 \mathrm{mg} / \mathrm{kg}$ animal body weight) on Vitamin C (Vit-C) level in albino rats exposed to noise-stress ( $\mu \mathrm{g} / \mathrm{mg}$ protein). Values are expressed as mean \pm S.D of six animals. Significance at $* p<0.05$; Significance at $* * p<0.01$; and c- Significance at $* * * p<0.001$. (CC-Cortex, CBCerebellum, CS-Striatum, BS- Brain stem, HY- Hypothalamus, HI- Hippocampus and ADR- Adrenal)

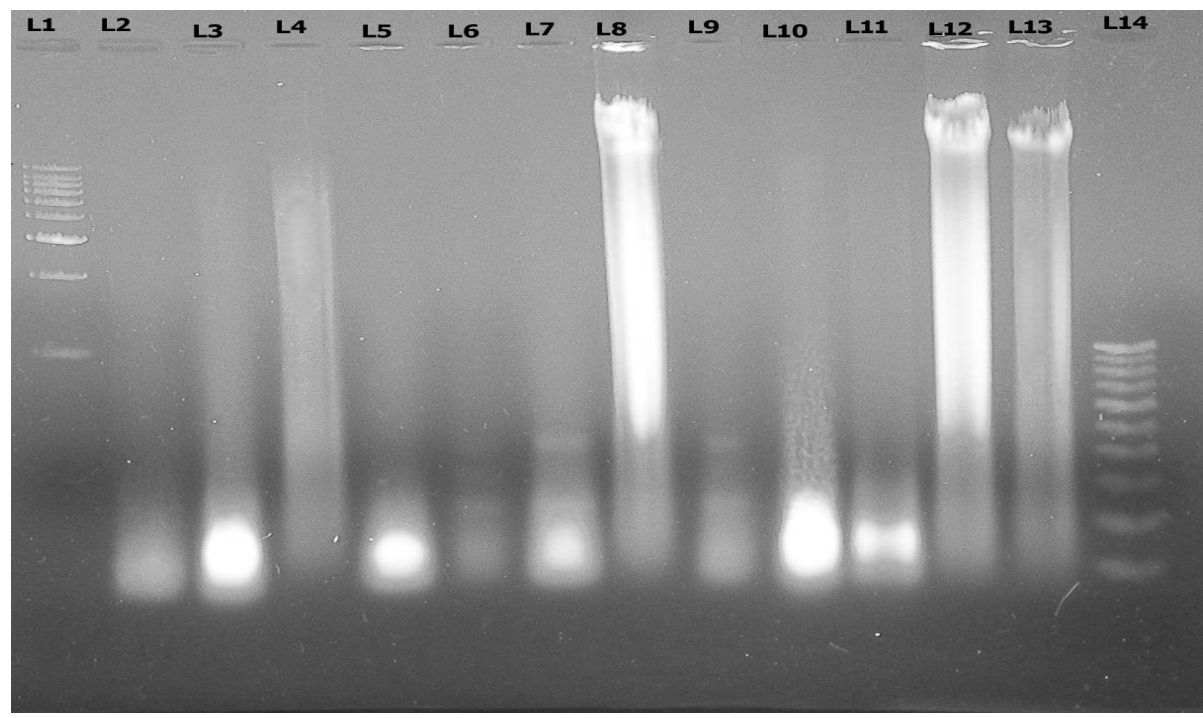

Fig. 6: Protective effect of I.tinctoria (300 mg/kg animal body weight) on noise induced DNA fragmentation (L1-1 KB Ladder, L2-Control CC, L3-I.tinctoria CC, L4- Noise CC, L5-Noise with I.tinctoria CC, L6- Control CB, L7-I.tinctoria CB, L8- Noise CB, L9- Noise with I.tinctoria CB, L10-Control HI, L11I.tinctoria HI, L12- Noise HI, L13-Noise with I.tinctoria HI, L14- 100bp Ladder) (CC-Cerebral Cortex, CB-Cerebellum, and HI- Hippocampus) 
Table 1: Protective effect of I.tinctoria ( $300 \mathrm{mg} / \mathrm{kg}$ animal body weight) on SOD level in albino rats exposed to noise-stress (units/mg protein).

\begin{tabular}{|c|c|c|c|c|}
\hline Organ & Group I & Group II & Group III & Group IV \\
\hline$\overline{\text { Cortex }}$ & $0.601 \pm 0.019$ & $1.037 \pm 0.090^{\mathrm{a}^{\mathrm{a} * *}}$ & $0.600 \pm 0.037^{b^{* * * *}}$ & $0.820 \pm 0.09^{\mathrm{a}^{* * *}}$ \\
\hline Cerebellum & $0.587 \pm 0.033$ & $0.805 \pm 0.062^{\mathrm{a}^{* * * *}}$ & $0.580 \pm 0.027^{\mathrm{b} * * *}$ & $0.679 \pm 0.101^{\mathrm{a}^{*} \mathrm{~b}^{*}}$ \\
\hline Striatum & $0.661 \pm 0.052$ & $0.791 \pm 0.097^{\mathrm{a}^{*}}$ & $0.634 \pm 0.082^{b^{*}}$ & $0.631 \pm 0.078^{\mathrm{b}^{*}}$ \\
\hline Brain stem & $0.555 \pm 0.067$ & $1.365 \pm 0.335^{\mathrm{a}^{* * * *}}$ & $0.562 \pm 0.048^{\mathrm{b}^{* * * *}}$ & $1.097 \pm 0.143^{\mathrm{a}^{* * * *} \mathrm{~b}^{*}}$ \\
\hline Hypothalamus & $1.871 \pm 0.155$ & $4.274 \pm 0.86^{\mathrm{a}^{* * *}}$ & $1.819 \pm 0.082^{\mathrm{b}^{* * * *}}$ & $2.728 \pm 0.431^{\mathrm{a}^{*} \mathrm{~b}^{* * * *}}$ \\
\hline Hippocampus & $1.294 \pm 0.068$ & $3.535 \pm 0.664^{\mathrm{a}^{* * * *}}$ & $1.207 \pm 0.078^{\mathrm{b}^{* * * *}}$ & $2.284 \pm 0.258^{\mathrm{a}^{* *} \mathrm{~b}^{* * *}}$ \\
\hline Adrenal & $1.803 \pm 0.289$ & $2.983 \pm 0.296^{\mathrm{a}^{* * * *}}$ & $1.888 \pm 0.213^{b^{* * * *}}$ & $2.296 \pm 0.068^{\mathrm{a}^{* *} \mathrm{~b}^{* * *}}$ \\
\hline
\end{tabular}

Data are represented as mean \pm S.D. (n=6).a- compared with control; b- compared with noise; Significance at $* p<0.05$; Significance at $* * p<0.01$; and $\mathrm{c}$ Significance at $* * * p<0.001$.

Table 2: Protective effect of I.tinctoria (300 mg/kg animal body weight) on catalase level in albino rats exposed to noise-stress $\left(\mu \mathrm{moles}\right.$ of $\mathrm{H}_{2} \mathrm{O}_{2}$ consumed / $\mathrm{mg}$ protein).

\begin{tabular}{lcccc}
\hline \multicolumn{1}{c}{ Organ } & Group I & Group II & Group III & Group IV \\
\hline Cortex & $4.810 \pm 0.108$ & $9.845 \pm 1.142^{\mathrm{a}^{* * * *}}$ & $4.817 \pm 0.307^{\mathrm{b}^{* * *}}$ & $6.634 \pm 0.846^{\mathrm{a}^{* * *}} \mathrm{~b}^{* * *}$ \\
Cerebellum & $4.876 \pm 0.205$ & $10.726 \pm 1.041^{\mathrm{a}^{* * *}}$ & $4.812 \pm 0.233^{\mathrm{b}^{* * * *}}$ & $6.174 \pm 0.618^{\mathrm{a}^{* *} \mathrm{~b}^{* * * *}}$ \\
Striatum & $4.835 \pm 0.239$ & $9.869 \pm 1.118^{\mathrm{a}^{* * * *}}$ & $4.647 \pm 0.593^{\mathrm{b}^{* * * *}}$ & $7.234 \pm 0.506^{\mathrm{a}^{* * * *} \mathrm{a}^{\mathrm{a}^{* * *}}}$ \\
Brainstem & $4.979 \pm 0.634$ & $2.783 \pm 2.987^{\mathrm{a}^{* * * *}}$ & $4.909 \pm 0.488^{\mathrm{b}^{* * * *}}$ & $8.233 \pm 0.857^{\mathrm{a}^{*} \mathrm{~b}^{* * *}}$ \\
Hypothalamus & $5.334 \pm 0.441$ & $11.743 \pm 2.285^{\mathrm{a}^{* * *}}$ & $5.457 \pm 0.250^{\mathrm{b}^{* * *}}$ & $7.689 \pm 1.186^{\mathrm{a}^{*} \mathrm{~b}^{* * *}}$ \\
Hippocampus & $5.637 \pm 0.401$ & $13.366 \pm 2.437^{\mathrm{a}^{* * *}}$ & $5.436 \pm 0.397^{\mathrm{b}^{* * * *}}$ & $8.201 \pm 0.99^{\mathrm{a}^{*} \mathrm{~b}^{* * *}}$ \\
Adrenal & $6.557 \pm 1.027$ & $16.793 \pm 1.857^{\mathrm{a}^{* * * *}}$ & $6.611 \pm 0.750^{\mathrm{b}^{* * * *}}$ & $11.714 \pm 1.850^{\mathrm{a}^{* * * *} \mathrm{~b}^{* * *}}$ \\
\hline
\end{tabular}

Data are represented as mean \pm S.D. $(\mathrm{n}=6)$. a- compared with control; b- compared with noise; Significance at $* p<0.05$; Significance at $* * p<0.01$; and c-

Significance at $* * * p<0.001$.

Table 3: Protective effect of I.tinctoria (300 mg/kg animal body weight) on Glutathione Peroxidase (GPX) level in albino rats exposed to noise-stress ( $\mu \mathrm{g}$ of GSH consumed / mg protein)

\begin{tabular}{|c|c|c|c|c|}
\hline Organ & Group I & Group II & Group III & Group IV \\
\hline Cortex & $4.928 \pm 0.295$ & $9.617 \pm 0.893^{\mathrm{a}^{* * * 6}}$ & $4.661 \pm 0.264^{\mathrm{b}^{* * * *}}$ & $6.983 \pm 0.394^{\mathrm{a}^{* * * * *} \mathrm{~b}^{* * * t}}$ \\
\hline Cerebellum & $4.127 \pm 0.164$ & $9.207 \pm 1.037^{\mathrm{a}^{* * * *}}$ & $4.172 \pm 0.265^{\mathrm{b}^{* * * *}}$ & $6.742 \pm 0.82^{\mathrm{a}^{* * * *} \mathrm{~b}^{* * * *}}$ \\
\hline Striatum & $4.825 \pm 0.357$ & $9.178 \pm 1.160^{\mathrm{a}^{* * * *}}$ & $4.482 \pm 0.731^{\mathrm{b}^{* * * *}}$ & $6.212 \pm 0.537^{\mathrm{a}^{*} \mathrm{~b}^{* * * *}}$ \\
\hline Brainstem & $4.559 \pm 0.605$ & $9.750 \pm 1.682^{\mathrm{a}^{* * * *}}$ & $4.366 \pm 0.340^{\mathrm{b}^{* * * *}}$ & $6.328 \pm 0.627^{\mathrm{a}^{*} \mathrm{~b}^{* * * *}}$ \\
\hline Hypothalamus & $3.977 \pm 0.377$ & $7.705 \pm 1.438^{\mathrm{a}^{* * * *}}$ & $3.895 \pm 0.318^{\mathrm{b}^{* * * *}}$ & $5.296 \pm 0.659^{\mathrm{a}^{*} \mathrm{~b}^{* * * *}}$ \\
\hline Hippocampus & $4.219 \pm 0.193$ & $9.474 \pm 1.669^{\mathrm{a}^{* * * *}}$ & $4.236 \pm 0.420^{\mathrm{b}^{* * * *}}$ & $6.259 \pm 0.909^{\mathrm{a}^{* * *} \mathrm{~b}^{* * * *}}$ \\
\hline Adrenal & $9.164 \pm 1.409$ & $15.773 \pm 1.954^{\mathrm{a}^{* * * *}}$ & $9.092 \pm 0.896^{\mathrm{b}^{* * * *}}$ & $12.277 \pm 0.93^{\mathrm{a}^{* *} \mathrm{~b}^{* * *}}$ \\
\hline
\end{tabular}

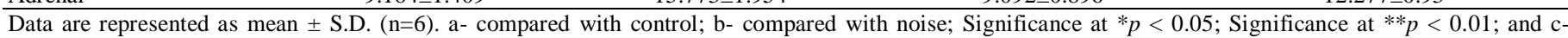
Significance at $* * * p<0.001$.

Table. 4: Protective effect of I.tinctoria (300 mg/kg animal body weight) on GST level in albino rats exposed to noise-stress (CDNB conjugate formed / min / $\mathrm{mg}$ protein).

\begin{tabular}{|c|c|c|c|c|}
\hline Organ & Group I & Group II & Group III & Group IV \\
\hline$\overline{\text { Cortex }}$ & $1.433 \pm 0.294$ & $2.791 \pm 0.153^{\mathrm{a}^{* \mathrm{*}}}$ & $1.199 \pm 0.170^{\mathrm{b}}$ & $2.123 \pm 0.127^{\mathrm{a}^{*}}$ \\
\hline Cerebellum & $1.364 \pm 0.235$ & $2.658 \pm 0.221^{\mathrm{a}^{* * * *}}$ & $1.338 \pm 0.291^{\mathrm{b}^{* * *}}$ & $2.221 \pm 0.138^{\mathrm{a}^{\mathrm{a}^{* *} \mathrm{~b}^{*}}}$ \\
\hline Striatum & $1.289 \pm 0.152$ & $2.279 \pm 0.273^{\mathrm{a}^{* * *}}$ & $1.196 \pm 0.151^{b^{* * *}}$ & $1.813 \pm 0.182^{\mathrm{a}^{* * *} \mathrm{~b} * *}$ \\
\hline Brainstem & $1.377 \pm 0.220$ & $3.303 \pm 0.228^{\mathrm{a}^{* * * *}}$ & $1.351 \pm 0.129^{\mathrm{b} * * *}$ & $2.274 \pm 0.203^{\mathrm{a}^{* * * *} \mathrm{~b}^{* * * *}}$ \\
\hline Hypothalamus & $1.524 \pm 0.313$ & $3.464 \pm 0.348^{\mathrm{a}^{* * * *}}$ & $1.669 \pm 0.153^{\mathrm{b}^{* * *}}$ & $2.578 \pm 0.256^{\mathrm{a}^{* * *} \mathrm{~b}^{\mathrm{b} * *}}$ \\
\hline Hippocampus & $1.553 \pm 0.255$ & $3.383 \pm 0.164^{\mathrm{a}^{* * * *}}$ & $1.784 \pm 0.245^{\mathrm{b}^{* * *}}$ & $2.523 \pm 0.223^{\mathrm{a}^{* * * *} \mathrm{~b}^{* * *}}$ \\
\hline Adrenal & $2.056 \pm 0.571$ & $4.937 \pm 0.663^{\mathrm{a}^{* * * *}}$ & $1.929 \pm 0.482^{\mathrm{b}^{* * *}}$ & $2.966 \pm 0.334^{a^{*} b^{* * *}}$ \\
\hline
\end{tabular}

Data are represented as mean \pm S.D. $(\mathrm{n}=6)$. a- compared with control; b- compared with noise; Significance at $* p<0.05$; Significance at $* * p<0.01$; and $\mathrm{c}$ Significance at $* * * p<0.001$.

Table 5: Protective effect of I.tinctoria (300 mg/kg animal body weight) on GR level in albino rats exposed to noise-stress (nM of NADPH oxidized / min / mg protein).

\begin{tabular}{|c|c|c|c|c|}
\hline Organ & Group I & Group II & Group III & Group IV \\
\hline$\overline{\text { Cortex }}$ & $0.077 \pm 0.003$ & $0.045 \pm 0.006^{\mathrm{a}^{*}}$ & $0.072 \pm 0.003^{b^{*}}$ & $0.058 \pm 0.004^{\mathrm{a}^{* \pi}}$ \\
\hline Cerebellum & $0.059 \pm 0.003$ & $0.037 \pm 0.0009^{\mathrm{a}^{* * * *}}$ & $0.060 \pm 0.001^{\mathrm{b}^{* * * *}}$ & $0.045 \pm 0.003^{\mathrm{a}^{* * *} \mathrm{~b}^{* * * *}}$ \\
\hline Striatum & $0.061 \pm 0.005$ & $0.043 \pm 0.001^{\mathrm{a}^{* * * *}}$ & $0.061 \pm 0.003^{\mathrm{b}^{* * * *}}$ & $0.049 \pm 0.003^{\mathrm{a}^{* * *} b^{*}}$ \\
\hline Brainstem & $0.059 \pm 0.005$ & $0.038 \pm 0.005^{\mathrm{a}^{* * *}}$ & $0.061 \pm 0.003^{\mathrm{b}^{* * *}}$ & $0.046 \pm 0.004^{\mathrm{a}^{* * *} \mathrm{~b}^{*}}$ \\
\hline Hypothalamus & $0.064 \pm 0.003$ & $0.032 \pm 0.006^{\mathrm{a}^{* * * *}}$ & $0.073 \pm 0.005^{\mathrm{b}^{* * * *}}$ & $0.045 \pm 0.005^{\mathrm{a}^{* * * *} \mathrm{~b}^{* *}}$ \\
\hline Hippocampus & $0.065 \pm 0.006$ & $0.027 \pm 0.005^{\mathrm{a}^{* * * *}}$ & $0.065 \pm 0.004^{b^{* * * *}}$ & $0.042 \pm 0.005^{a^{* * *} b^{* *}}$ \\
\hline Adrenal & $0.085 \pm 0.008$ & $0.053 \pm 0.002^{\mathrm{a}^{* * * *}}$ & $0.083 \pm 0.001^{\mathrm{b}^{* * * *}}$ & $0.074 \pm 0.002^{\mathrm{a}^{* * *} \mathrm{~b}^{* * *}}$ \\
\hline
\end{tabular}

Data are represented as mean \pm S.D. $(\mathrm{n}=6)$. a -compared with control; b- compared with noise; Significance at $* p<0.05$; Significance at $* * p<0.01$; and Significance at $* * * p<0.001$.

Table 6: Protective effect of I. tinctoria ( $300 \mathrm{mg} / \mathrm{kg}$ animal body weight) on motor behavior in Albino Rats Exposed to noise-stress.

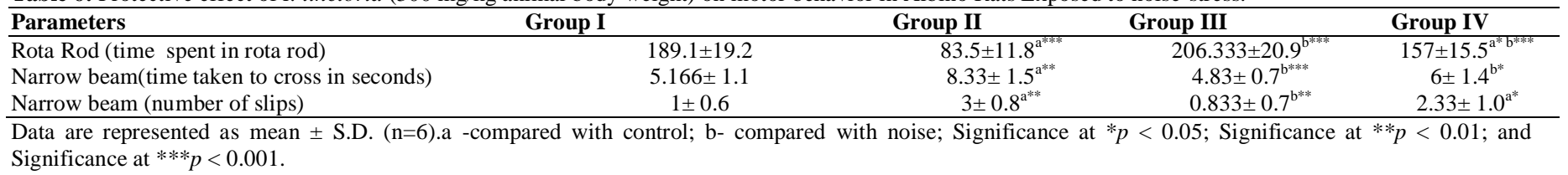


Table 7: Protective effect of I.ntigofera (300 mg/kg animal body weight) on Elevated plus maze (anxiety) in albino rats exposed to noise-stress

\begin{tabular}{|c|c|c|c|c|}
\hline Parameters & Group I & Group II & Group III & Group IV \\
\hline No of open arm entry & $8.5 \pm 1.0$ & $2 \pm 1.6^{\mathrm{a}^{* k *}}$ & $7.16 \pm 2.6^{b^{* * *}}$ & $3.33 \pm 0.8^{\mathrm{a}^{* \cdots *}}$ \\
\hline Time spent in open arm entry & $274.8 \pm 14.5$ & $107 \pm 19.0^{\mathrm{a}^{* * *}}$ & $233.8 \pm 50.0^{\mathrm{b}^{* * * *}}$ & $153 \pm 32.8^{\mathrm{a}^{* * * *} \mathrm{~b}^{*}}$ \\
\hline No of closed arm entry & $2.66 \pm 0.8$ & $5.66 \pm 1.0^{\mathrm{a}^{* * * *}}$ & $3 \pm 1.0^{\mathrm{b}^{* *}}$ & $4.83 \pm 0.9^{\mathrm{a}^{* *}}$ \\
\hline Time spent in closed arm entry & $130.6 \pm 19.8$ & $248.8 \pm 28.5^{\mathrm{a}^{* * *}}$ & $132.6 \pm 26.8^{\mathrm{b}^{* * *}}$ & $192 \pm 26.5^{\mathrm{a}^{* *} \mathrm{~b}^{* *}}$ \\
\hline
\end{tabular}

\section{DNA fragmentation}

Electrophorosis of DNA isolated from cortex, cerebellum, hippocampus regions and its shows smear pattern (Fig 6). This result indicated that noise had the potency to induce DNA damage in the brain region. This result justify by Luann $e t$ al. (2002) who reported that, oxidative DNA damage is associated with intense noise exposure in the rat. One of the possibility is that DNA can be an early target of damage in mammals, such that strand breakage occurs before detectable lipid peroxidation or protein damage (Schraufstatter et al., 1986). The damage may result from direct ROS activity or may be an indirect result of ROS lipid peroxidation. I. tinctoria with noise exposed animal brain regions are not showing any fragmentation and this result further concluded that I. tinctoria clearly reduced the DNA damage.

\section{Locomotor and anxiety level}

The effect on motor coordination are assessed using a rota-rod apparatus. The results are summarized in Table 6. In the present study noise stress significantly $(\mathrm{P}<0.001)$ decreased the motor coordination. Plant extract showed significant decrease in the motor coordination score and fall of time of the rat from the rotating rod justify that plant restored the motor coordination activity. In the present study, the rats were tested for the balance and motor coordination on the narrow beam (Table 6). The results of narrow beam showed compromised motor function in sub-acute noise exposed rats. The time taken to cross and number of slips the beam are significantly $(\mathrm{P}<0.01)$ increase in sub-acute exposed rats when compare with control group. The noise-stress induced change in the motor coordination are significantly decrease number of slips and time taken to cross enhanced in noise-stress with I. tinctoria group. The same result suggested that Satyndra et al. (2013) the treatment of intoxicated mice with plant seed extract improves motor behavior, due to reduction in oxidative stress in striatum of the brain.

Elevated plus maze is used to evaluate psychomotor performance and emotional aspects of rats. Anxiety disorders are due to involvement of GABAergic, serotonergic, involvement. Values are the number of entries into open and closed arms in 5 min (Mean \pm S.D) (Table 7). The adrenergic and dopamanergic system have also been shown to play a role in anxiety (Kishore et al., 2012). In sub-acute noise stress, significantly ( $\mathrm{P}<0.001)$ decrease in the open arm entry and time spend in open arm. Results shows that on sub-acute exposure of noise cause anxiety in rats. Results shows that plant extracts with noise stressed rats exhibited significant increase in the number of open arm entries. The number of arm entries, but decreases in time spent in closed arm reflects plants revealed anxiolytic activity. Earlier reports on the chemical constituents of plants and their pharmacology suggest that plants containing flavonoids, alkaloids, phenolic acids, essential oil, saponins and tannins possess activity against many locomotor, anxiety disorders (Bhatacharya and Satyan, 1997). Renukadevi et al. 2011 who reported that I. tinctoria contain flavonoids and phenolics abundantly. The results of behavioral tests showed that impaired motor function and anxiety in noise exposed group. Interestingly, I. tinctoria with noise exposed rats shows significant improvement in all the behavior test. This justify I. tinctoria is potential to renovate locomotory and anxiety level.

\section{CONCLUSION}

The results indicate that oxidative damage occurred in the rat brain and adrenal when exposed to noise-stress. The aqueous extract I. tinctoria treatment restored the activities and levels of antioxidant machinery in the rat brain upon noise-stress. Interestingly, I. tinctoria treated group prevented the cortical neuronal and adrenal alteration which is observed in noise-stress exposed rat. This effect might be due to the antioxidant action of the I. tinctoria.

So the present study proposes that I. tinctoria supplementation may utilize antioxidant effect and can be regarded as a neuroprotective drug against stress.

\section{ACKNOWLEDGEMENT}

The financial assistance provided by the UGC UPEPhase II (No: 2013/PFEP/C3/280) from University of Madras.

\section{CONFLICT OF INTERESTS}

No conflict of interests to declare.

\section{REFERENCE}

Antonio, C. Oxidative stress in neurodegeneration: mechanism and therapeutic perspectives. Curr Top Med Chem, 2001; 1: 553-568.

Ashok I, Sheeladevi R. Effect of chronic exposure to aspartame on oxidative stress in the brain of albino rats. J Biosci, 2012; 37(4): 679688.

Bharath S, Hsu M, Kaur D, Rajagopalan S, Andersen JK. Glutathione, iron and Parkinson's disease. Biochem Pharmacol, 2002; 64: 1037-1048.

Bhatacharya SK, Satyan KS. Experimental methods for evalution of psychotropic agents in rodents: Anti-anxiety agents. Indian $J$ Exp Biol, 1997; 35: 565-75.

Borriello A, Roberto R, Della RF, Iolascon A. Proliferate and survive: cell division cycle and apoptosis in human neuroblastoma. Haematologica, 2002; 87(2): 196-214. 
Dunham NW, Miya TS. A note on a simple apparatus for detecting neurological deficit in rats and mice. J Am Pharm Assoc, 1957; 46: 208-209.

Gilgun-Sherki Y, Melamed E, Offen D. Oxidative stress induced-neurodegenerative diseases: the need for antioxidants that penetrate the blood brain barrier. Neuropharmacology, 2001; 40: 959- 975.

Glowinski J, Iverson LL. Regional studies of catecholamines in the rat brain. J Neurochem, 1996; 13: 655-669.

Kishore RN, Anjaneyulu N, Ganesh MN, Sravya N. Evaluation of anxiolytic activity of ethanolic extract of Foeniculum vulgare in mice model. Int J Pharm Pharm Sci, 2012; 4: 584.

Kolb B, Whishaw IQ. Dissociation of the contributions of the prefrontal, motor, and parietal cortex to the control of movement in the rat: an experimental review. Can J Psychol, 1983; 37: 211-232.

Kvetnansky R, Jelokova J, Rusnak M. Novel stressors exaggerate tyrosine hydroxylase gene expression in the adrenal medulla of rats exposed to long-term cold stress. Stress: Neural Endocrine and Molecular studies, 2002; 1: 121-128.

Lidija R, Vesna S, Branka J, Dajana T. Effect of glutamate antagonists on nitric oxide production in rat brain following intra hippocampal injection. Arch Biol Sci, 2007; 59 (1): 29-36.

Lopaczyski W, Zeisel SH. Antioxidants, programmed cell death, and cancer. Nutr Res, 2001; 21: 295-307.

Lowry OH, Rosebrough NJ, Farr AL, Rose JR. Protein measurement with the Folin phenol reagent. J Biol Chem, 1951; 193: 263 275.

Luann EV, William JM, John RF, Patricia IM, Mark AT. Oxidative DNA damage is associated with intense noise exposure in the rat. Hear Res, 2002; 164: 29-38.

Manikandan S, Sheela Devi R. Antioxidant property of $\alpha$ asarone against noise-stress-induced changes in different regions of rat brain. Pharmacol Res, 2005; 52: 467-474.

Marklund S, Marklund G. Involvement of the superoxide anion radical in the autooxidation of pyrogallol and a convenient assay for superoxide dismutase. Eur J Biochem, 1974; 47: 469-474.

McIntosh LJ, Sapolsky RM. Glucocorticoids increase the accumulation of reactive oxygen species and enhance adriamycin-induced toxicity in neuronal culture. Exp Neurol, 1996; 141: 201-206.

Moron MS, Difieree JW, Mannervik KB. Levels of glutathione, reductase and glutathione-S-transferase activities in rat lung and liver. Biochem Biophys Acta, 1979; 582: 67-68.

Moshage H, Kok B, Huizenga JR, Jansen PL. Nitrite and nitrate determinations in plasma: a critical evaluation. Clin Chem, 1995; 41:892896.

Nagarajan A, Sellamuthu M. Antioxidant and free radical scavenging potential of different solvent extracts of Indigofera tinctoria $\mathrm{L}$. Leaves. Int J Phar Pharmacol Sci, 2013; 5: 142-147.

Ohkawa H, Osishi N, Yagi K. Assay for lipid peroxide in animal tissue by thiobarbituric acid reaction. Anal Biochem, 1979; 251: $351-358$

Omaye ST, Turnbull JD, Sauberlich HE. Selected methods for the determination of ascorbic acid in animal cells, tissues and fluids. Methods Enzymol, 1979; 62: 1-11.
Pellow S, File SE. Anxiolytic and anxiogenic drug effects on exploratory activity in an elevated plus-maze: a novel test of anxiety in the rat. Pharmacol Biochem Behav, 1986; 24: 525- 529.

Ramsey JM. Modern stress and the disease process. In: Basic Physiology. California: Addison-Wesley Publishing Company. 1982; $177-$ 79 .

Reha D, Hakan M, Hasan Y, Kagam U, Abdullah A, Muzaffer A. Noise induced oxidative stress in Rat. Eur J Gen Med, $2009 ; 6$ (1): 20 24.

Renukadevi KP, Suhani, Sultana S. Determination of antibacterial, antioxidant and cytotoxicity effect of I. tinctoria on lung cancer cell line NCI-h69. Int J Pharmacol, 2011; 7 (3): 56-362.

Rotruck JT, Pope AL, Ganther HE, Swanson AB, Hafeman DG, Hoekstra WG. Selenium: biochemical role as a component of glutathione peroxidase. Science, 1973; 179: 588-590.

Samson J, Sheela Devi R, Ravindran R, Senthilvelan M. Effect of noise stress on free radical scavenging enzymes in brain. Environ Toxicol Pharmacol, 2005; 20: 142-148.

Satyndra KY, Jay P, Shikha C, Surya PS. Mucuna pruriens seed extract reduces oxidative stress in nigrostriatal tissue and improves neurobehavioral activity in paraquat-induced Parkinsonian mouse model. Adv Biosci Biotechnol, 2013; 4: 1-9.

Schraufstatter IU, Hinshaw DB, Hyslop PA, Spragg RG, Cochrane CG. Oxidant injury of cells. DNA strand-breaks activate polyadenosine diphosphate-ribose polymerase and lead to depletion of nicotinamide adenine dinucleotide. J Clin Invest, 1986; 77: 1312-1320.

Schulz JB, Lindenau J, Seyfried J, Dichgans J. Glutathione oxidative stress and neurodegeneration. Eur J Biochem, 2000; 267: 49044911.

Sedlack J, Lindsay RH. Estimation of total protein bound and non proteinsuiphydryl in the tissue with Ellman,s reagent. Anal Biochem, 1968; 25: 192-205.

Seidman MD. Effects of dietary restriction and antioxidants on presbyacusis. Laryngoscope, 2000; 110: 727-738.

Senthilkumar A, Venkatesalu V. Photochemical analysis and antibacterial activity of the essential oil of Clausenaanisata (Willd.) hook. f. ex benth. Int J Integrative Biol, 2009; 5: 116-120. 47: 389-394.

Sinha AK. Colorimetric assay of catalase. Anal Biochem, 1972

Vidyasagar N, Karunakar MS, Reddy K, Rajnarayana T, Surender DR, Krishna. Oxidative stress and antioxidant status in acute organophosphorous insecticide poisoning. Ind J Pharmacol, 2004; 36: 7679.

Yun-Zhong F, Sheng Y, Guoyao Wu. Free radicals, antioxidants, and nutrition. Nutrition, 2002; 18: 872- 879 .

\section{How to cite this article:}

Sakthivel Srinivasan, Wankupar Wankhar, Sheeladevi Rathinasamy, Ravindran Rajan. Neuroprotective effects of Indigofera tinctoria on noise stress affected Wistar albino rat brain. J App Pharm Sci, 2015; 5 (06): 058-065. 